\title{
Pengamatan Pertumbuhan Ayam Kampung pada Kondisi Pemeliharaan Intensif di Kabupaten Manokwari
}

\author{
Nani Zurahmah ${ }^{*}$, Oeng Anwarudin ${ }^{1}$ \\ ${ }^{1}$ Program Studi Penyuluhan Peternakan dan Kesejahteraan Hewan, Politeknik Pembangunan \\ Pertanian Manokwari \\ *Corresponding author: nazur201162@gmail.com
}

\begin{abstract}
Abstrak
Penelitian ini bertujuan untuk mendeskripsikan pertumbuhan ayam kampung yang dipelihara intensif di kabupaten Manokwari. Sebanyak 65 ayam kampung (29 jantan dan 36 betina), berasal dari hasil penetasan 144 butir telur ayam kampung yang diambil secara acak di beberapa peternak di wilayah kabupaten Manokwari, provinsi Papua Barat, digunakan dalam penelitian ini. Ayam kampung hasil penetasan ini dipelihara secara intensif hingga berumur 4 bulan. Selama pemeliharaan, ayam-ayam diberi ransum berkadar protein 21 - 23\% dan ME. 3000 - $3200 \mathrm{kcal} / \mathrm{kg}$, dan ditimbang berat badannya setiap bulan. Hasil penelitian menunjukkan bahwa rata-rata berat badan ayam kampung penelitian pada yang jantan dan betina umur 1 bulan sebesar 363,8 $\pm 48,1 \mathrm{~g}$ dan $321,9 \pm 55,8 \mathrm{~g}$; umur 2 bulan sebesar $820,3 \pm 153,9 \mathrm{~g}$ dan $673,6 \pm 140,2 \mathrm{~g}$; umur 3 bulan sebesar $1.324,5 \pm 319,6 \mathrm{~g}$ dan $1.073,6 \pm 265,1 \mathrm{~g}$; umur 4 bulan sebesar $1.877,6 \pm 449,5 \mathrm{~g}$ dan $1.503,3 \pm 416,0 \mathrm{~g}$; dan pertambahan berat badan (PBB) umur 1 hingga 4 bulan sebesar $1.513,8 \pm 426,8 \mathrm{~g}$ dan $1.181,4 \pm 381,9$ g. Rata-rata berat badan dan PBB jantan dan betina di atas berbeda signifikan $(\mathrm{P}<0,05)$. Informasi hasil-hasil penelitian terdahulu pada kondisi serupa (pemeliharaan intensif) memberikan hasil yang beragam sehingga disimpulkan bahwa keragaman genetik pertumbuhan ayam kampung tergolong tinggi.
\end{abstract}

Kata kunci: Ayam kampung, Manokwari, Pemeliharaan intensif, Pertumbuhan

\begin{abstract}
This study aims to describe the growth of local chickens under intensive rearing conditions in Manokwari district. A total of 65 local chickens (29 males and 36 females), derived from the hatching of 144 local chicken eggs taken at random from several breeders in the Manokwari district, were used in this study. These hatched local chicks (DOC) were reared intensively until they were 4 months old. During rearing, the chickens were given rations containing 21-23\% protein and ME. $3000-3200 \mathrm{kcal} / \mathrm{kg}$, and weighed every month. The results showed that the average body weight of

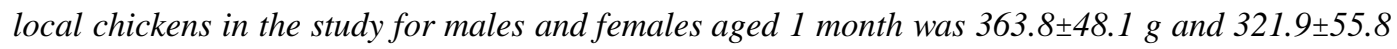
$\mathrm{g} ; 2$ months of age $820.3 \pm 153.9 \mathrm{~g}$ and $673.6 \pm 140.2 \mathrm{~g} ; 3$ months old of 1,324,5 $\pm 319.6 \mathrm{~g}$ and

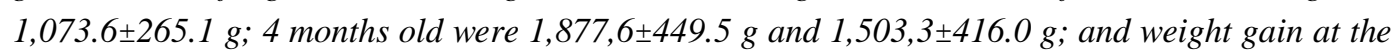
age of 1 to 4 months of 1,513.8 $\pm 426.8 \mathrm{~g}$ and $1,181.4 \pm 381.9 \mathrm{~g}$, respectively. The average body weight and weight gain of males and females above were significantly different $(P<0.05)$. Information on the results of previous studies under similar conditions (intensive rearing) gave mixed results, so it was concluded that the genetic diversity of local chicken growth was high.
\end{abstract}

Keywords: Growth, Intensive rearing, Local chicken, Manokwari 
Prosiding Seminar Nasional Pembangunan dan Pendidikan Vokasi Pertanian

Politeknik Pembangunan Pertanian Manokwari, 31 Juli 2021

e ISSN : 2774-1982

DOI : https://doi.org/10.47687/snppvp.v2i1.190

\section{PENDAHULUAN}

Dalam dunia perunggasan dikenal dua kelompok ayam, yaitu ayam ras dan ayam bukan ras (buras). Ayam kampung termasuk ayam buras yang paling dikenal masyarakat dan merupakan salah satu jenis unggas yang tersebar di desa maupun di kota karena ternak ini merupakan bagian hidup dari sebagian masyarakat Indonesia (Yuwanta et al., 2002), terutama bagi masyarakat pedesaan untuk meningkatkan taraf hidupnya. Walaupun demikian, pertumbuhan ayam kampung lebih lambat dibandingkan dengan ayam ras, sebab pada umumnya sistem pemeliharaannya masih tradisional, dan juga kemampuan genetik ayam kampung kurang dapat mendukung untuk tumbuh pesat. Oziana et al. (2019) melaporkan bahwa sistem pemeliharaan ayam kampung semi intensif lebih dominan dibandingkan dengan sistem pemeliharaan intensif, sedangkan kontribusi pendapatan per tahun dari pemeliharaan ayam kampung sistem pemeliharaan semi intensif lebih tinggi dibandingkan sistem pemeliharaan intensif.

Laporan beberapa hasil survei pada peternakan rakyat menunjukkan bahwa ayam kampung di Manokwari memiliki keragaman produktifitas yang tinggi (Haryani, 1999; Rahayu, 1990; Lebang, 2002; Mu'in, 2000; Lumatauw et al., 1995; Zurahmah, 2019). Hasil pengukuran Haryani (1999) terhadap tujuh ukuran tubuh (panjang dada, lingkar dada, panjang betis, panjang paha, panjang shank, lingkar shank, dan bobot badan) dari 328 ayam kampung dewasa di Manokwari ditemukan bahwa tingkat keragamannya cukup tinggi [Distrik Manokwari (Kelurahan Amban): 8,14 - 20,87\%; Oransbari (kelurahan Sidomulyo): 6,02 - 17,59\%; dan Warmare (kelurahan Udapi Hilir): 5,16 - 19,02\%]. Keragaman yang tinggi ditemukan pula pada bobot karkasnya (Rahayu, 1990) maupun berat telur dan jumlah telur yang dihasilkan per siklus bertelurnya (Lebang, 2002). Potensi genetik dari ayam kampung di Manokwari juga cukup tinggi karena nilai heritabilitas dari beberapa ukuran tubuhnya: panjang shank, panjang betis, panjang paha, lingkar dada, panjang dada, lebar dada, dan panjang dada, tergolong sedang $(0,1$ - 0,3) sampai tinggi $(>0,3)$ (Mu'in, 2000). Zurahmah (2019) yang melakukan pengamatan performans terhadap 240 ayam kampung yang dipelihara dengan manajemen tradisional di Kabupaten Manokwari menemukan bahwa rata-rata berat badan jantan dan betina dewasa (umur \pm 1 tahun ) adalah $2368.5 \pm 626,3 \mathrm{~g}$ dan 1876,1 $\pm 413 \mathrm{~g}$, dan kedua angka performans ini lebih tinggi daripada laporan yang sama di daerah lain, terutama di Indonesia bagian tengah dan barat. Hal ini diduga karena ketersediaan pakan alami untuk ayam kampung yang 
Prosiding Seminar Nasional Pembangunan dan Pendidikan Vokasi Pertanian

Politeknik Pembangunan Pertanian Manokwari, 31 Juli 2021

e ISSN : 2774-1982

DOI : https://doi.org/10.47687/snppvp.v2i1.190

dipelihara tradisional di wilayah Manokwari masih melimpah dan praktik inbreeding dapat dihindari.

Temuan-temuan di atas menunjukkan bahwa kinerja pertumbuhan, produksi maupun reproduksi ayam kampung di Manokwari dapat ditingkatkan baik dari aspek genetik, pakan, maupun manajemen pemeliharaannya. Penelitian ini bertujuan melakukan pengamatan pertumbuhan ayam kampung dalam kondisi menajemen pemeliharaan intensif, dimana ayam penelitian dipelihara dalam kandang umbaran terbatas dan diberi ransum berkualitas. Pengamatan dilakukan dengan menimbang berat badan pada umur 1 , 2, 3, umur 4 bulan.

\section{METODE}

Materi yang digunakan dalam kegiatan penelitian ini adalah 65 ekor ayam kampung (29 jantan dan 36 betina), berasal dari hasil penetasan 144 butir telur ayam kampung yang diambil secara acak di beberapa peternak di wilayah kabupaten Manokwari, provinsi Papua Barat.

Pelaksanaan penelitian dilakukan di Reremi Permai Manokwari, selama lima bulan (Maret sd. Juli 2020), dengan perincian 1 bulan untuk kegiatan pengumpulan telur tetas dan penetasan dan 4 bulan untuk kegiatan pemeliharaan ayam penelitian hasil penetasan. Sebanyak 144 butir telur tetas ayam kampung dikumpulkan dari beberapa peternak rakyat di wilayah kabupaten Manokwari. Telur-telur ini kemudian ditetaskan menggunakan alat tetas buatan.

Anak-anak ayam kampung (DOC) dari hasil penetasan dipelihara dalam kondisi pemeliharaan intensif hingga umur 4 bulan. Pemeliharaan pada bulan pertama dilakukan dalam kandang indukan (brooder), sedangkan pemeliharaan umur 1 hingga 4 bulan dilakukan secara umbaran terbatas dalam suatu kandang grower beralaskan serbuk gergaji. Sebelum dipelihara dalam umbaran terbatas, ayam-ayam penelitian diberi identitas (wing taq). Selama pemeliharaan diberi ransum berkualitas (mengandung protein 21-23\% dengan ME. 3000 - $3200 \mathrm{kcal} / \mathrm{kg}$ ) dan pemberian air minum yang dicampur dengan mutivitamin dan mineral (Broiler Vit). Ransum dan air minum diberikan secara ad libitum. Berat badan ayam penelitian ditimbang pada umur 1, 2, 3 dan 4 bulan.

Data berat badan ayam penelitian yang diperoleh dianalisis secara deskriptif untuk memperoleh gambaran pertumbuhan (rata-rata berat badan bulanan dan pertambahan berat badannya) pada jantan maupun betina. Selanjutnya dilakukan uji t dua sampel independen 
Prosiding Seminar Nasional Pembangunan dan Pendidikan Vokasi Pertanian

Politeknik Pembangunan Pertanian Manokwari, 31 Juli 2021

e ISSN : 2774-1982

DOI : https://doi.org/10.47687/snppvp.v2i1.190

pada tingkat signifikansi $95 \%$ untuk membandingkan pertumbuhan ayam penelitian yang jantan dan betina.

\section{HASIL DAN PEMBAHASAN}

Rata-rata berat badan hasil penimbangan bulanan dan pertambahan berat badan sejak umur 1 sampai 4 bulan yang dikelompokkan berdasarkan jenis kelamin, disajikan pada Tabel 1, dimana terlihat bahwa rata-rata berat badan ayam kampung penelitian menunjukkan peningkatan dari waktu ke waktu pengamatan. Hasil analisis statistik menunjukkan bahwa rata-rata berat badan semua umur pengamatan dan PBB umur 1 - 4 bulan pada jantan dan betina berbeda signifikan $(\mathrm{P}<0,05)$. Selain itu, dari Tabel 1 dapat diketahui pula bahwa semakin meningkatnya umur pengamatan semakin meningkat pula keragamannya. Hal ini merupakan fenomena yang umum terjadi pada pertumbuhan hewan.

Tabel 1. Rata-rata berat badan dan pertambahan berat badan ayam kampung penelitian pada umur 1, 2, 3, dan 4 bulan.

\begin{tabular}{lcccc}
\hline \hline $\begin{array}{l}\text { Pengamatan } \\
\text { berat badan }(\mathrm{g})\end{array}$ & Jantan $(\mathrm{n}=29)$ & $\mathrm{KK}(\%)$ & Betina $(\mathrm{n}=36)$ & $\mathrm{KK}(\%)$ \\
\hline Umur 1 bulan & $363,8 \pm 48,1^{\mathrm{a}}$ & 13,2 & $321,9 \pm 55,8^{\mathrm{b}}$ & 17,3 \\
Umur 2 bulan & $820,3 \pm 153,9^{\mathrm{a}}$ & 18,8 & $673,6 \pm 140,2^{\mathrm{b}}$ & 20,8 \\
Umur 3 bulan & $1324,5 \pm 319,6^{\mathrm{a}}$ & 24,1 & $1073,6 \pm 265,1^{\mathrm{b}}$ & 24,7 \\
Umur 4 bulan & $1877,6 \pm 449,5^{\mathrm{a}}$ & 23,9 & $1503,3 \pm 416,0^{\mathrm{b}}$ & 27,7 \\
PBB umur 1 - 4 bulan & $1513,8 \pm 426,8^{\mathrm{a}}$ & 28,2 & $1181,4 \pm 381,9^{\mathrm{b}}$ & 32,3 \\
\hline
\end{tabular}

Keterangan: Pertambahan Berat Badan (PBB); Superskrip yang berbeda dalam satu baris menunjukkan terdapat perbedaan signifikan $(\mathrm{P}<0,01)$.

Penampilan pertumbuhan ayam kampung yang ditemukan dalam penelitian ini relatif lebih tinggi apabila dibandingkan dengan rata-rata berat badan ayam kampung pada manajemen pemeliharaan yang sama (intensif) dari beberapa laporan penelitian terdahulu. Astuti et al. (1979) melaporkan bahwa pertumbuhan ayam kampung yang dipelihara intensif sampai umur 12 minggu ( \pm 3 bulan) mencapai berat badan rata-rata 1086,30 g untuk jantan dan 636,16 g untuk betina. Tanpa menyebutkan jenis kelamin, Creswell dan Gunawan (1982) melaporkan bahwa ayam kampung yang dipelihara secara intensif mencapai bobot badan 708 gram pada umur 12 minggu ( \pm 3 bulan). Hasim (2005) melaporkan bahwa dengan pemeliharaan intensif, berat badan ayam kampung pada umur 1 bulan adalah $260 \mathrm{~g}$ untuk jantan dan $225 \mathrm{~g}$ untuk betina, umur 2 bulan mencapai 626,27 g untuk jantan dan 573,33 g untuk betina. Rajab (2018) melaporkan hasil pengamatannya pada 101 ekor ayam kampung yang dipelihara intensif bahwa rata-rata bobot badan pada 
Prosiding Seminar Nasional Pembangunan dan Pendidikan Vokasi Pertanian

Politeknik Pembangunan Pertanian Manokwari, 31 Juli 2021

e ISSN : 2774-1982

DOI : https://doi.org/10.47687/snppvp.v2i1.190

umur 4 minggu ( \pm 1 bulan) sebesar 337,44 g, dan pada umur 8 minggu ( \pm 2 bulan) sebesar $732,21 \mathrm{~g}$. Bobot badan ayam kampung pada umur 8 minggu ( \pm 2 bulan) adalah 549,97 g, dan pada umur 12 minggu ( \pm 3 bulan) adalah 751,57 g (Mulyadi et al., 1981). Setiawan (2007) menyebutkan bahwa rata-rata berat badan pada umur 1 bulan sebesar $148 \mathrm{~g}$, umur 2 bulan sebesar $370 \mathrm{~g}$, umur 3 bulan sebesar $708 \mathrm{~g}$, dan umur 4 bulan sebesar $932 \mathrm{~g}$. Angkaangka yang ditemukan peneliti terdahulu di atas ini (pada sistem pemeliharaan yang sama, intensif) masih jauh lebih rendah dibandingkan dengan rata-rata berat badan pada umur yang sama yang ditemukan pada penelitian ini. Apalagi bila hasil penelitian ini dibandingkan dengan penelitian ayam kampung yang dipelihara tradisional maupun semiintensif jauh lebih rendah berat badannya sebagaimana dilaporkan Prasetyo et al. (1985) bahwa berat ayam kampung umur 90 hari ( \pm 3 bulan) yang dipelihara trasional adalah 425,19 gram dan yang dipelihara semi-intensif 531,88 gram.

Berdasarkan data-data hasil penelitian di atas terlihat bahwa dalam manajemen pemeliharaan yang sama, yaitu intensif, penampilan berat badan ayam kampung pada umur yang sama dilaporkan antar para peneliti adalah beragam. Hal ini membuktikan bahwa keragaman genetik sifat pertumbuhan ayam kampung tergolong beragam. Fenomena ini dapat dijelaskan melalui teori yang dikemukakan oleh Warwick et al. (1983) dan Hardjosubroto (1994) bahwa penampilan suatu sifat dipengaruhi oleh faktor genetik dan faktor lingkungan. Pengaruh faktor genetik dapat berupa perbedaan antar bangsa, antar populasi, bahkan antar individu. Sedangkan pengaruh faktor lingkungan antara lain dapat berupa perbedaan kualitas dan kuantitas pakan yang diberikan, perbedaan iklim mikro suatu wilayah, perbedaan sistem pemeliharaan (intensif, semi-intensif, atau ekstensif), dan lain-lain. Pada kasus dimana pemeliharaan yang diterapkan adalah sama, yaitu sistem pemeliharaan intensif, baik yang diterapkan pada ayam kampung penelitian ini maupun yang diterapkan pada beberapa laporan hasil penelitian sebagai pembanding sebagaimana yang disebutkan di atas, artinya faktor lingkungan diasumsikan sama, atau pengaruh lingkungan dianggap tidak ada (nol). Karena pengaruh faktor lingkungan dianggap tidak ada (nol), maka perbedaan penampilan sifat (pertumbuhan) ayam kampung yang muncul antara hasil penelitian ini dan beberapa laporan hasil penelitian yang digunakan sebagai pembanding semata-mata adalah akibat pengaruh perbedaan genetik. Berdasarkan teori ini maka diketahui bahwa keragaman genetik sifat pertumbuhan ayam kampung adalah tergolong tinggi. Sehubungan dengan itu maka penelitian ke depan yang menggunakan ayam kampung sebagai materi percobaan disarankan perlu bersikap lebih hati-hati dalam 
Prosiding Seminar Nasional Pembangunan dan Pendidikan Vokasi Pertanian

Politeknik Pembangunan Pertanian Manokwari, 31 Juli 2021

e ISSN : 2774-1982

DOI : https://doi.org/10.47687/snppvp.v2i1.190

mengantisipasi keragaman sifat pertumbuhan ayam kampung yang tinggi ini karena dapat menurunkan akurasi hasil penelitian, terutama apabila perlakuan yang diberikan menyangkut aspek lingkungan.

\section{KESIMPULAN DAN SARAN}

Berdasarkan hasil penelitian ini maka dapat disimpulkan bahwa pemeliharaan intensif pada ayam kampung mampu meningkatkan pertumbuhannya. Namun, dalam kondisi manajemen pemeliharaan yang sama (intensif), dilaporkan beberapa peneliti bahwa respon pertumbuhan ayam kampung berbeda-beda, karena tergantung dari populasi ayam kampung yang diamati. Hal ini menunjukkan bahwa keragaman genetik sifat pertumbuhan ayam kampung antar individu maupun antar populasi masih relatif tinggi.

\section{DAFTAR PUSTAKA}

Astuti, M., H. Mulyadi, \& J. Purba. (1979). Pengukuran Parameter Genetik Ayam Kampung. Laporan Penelitian 296/PIT/DPM/78. Universitas Gadjah Mada. Yogyakarta.

Creswell, D.C. \& B. Gunawan. (1982). Pertumbuhan Badan dan Produksi Telur dari 5 Strain Ayam Sayur pada Sistem Peternakan Intensif. Prosiding Seminar Penelitian Peternakan. Bogor.

Hardjosubroto, W. (1994). Aplikasi Pemuliabiakan Ternak di Lapangan. Gramedia Widiasarana Indonesia. Jakarta.

Haryani, E. (1999). Keragaman Morfologi dan Morfogenetik Ayam Kampung di Kabupaten Manokwari. Skripsi. Fakultas Pertanian, Universitas Cenderawasih, Manokwari.

Hasim. (2005). Heterosis Bobot Badan Ayam Kampung Umur 2 Bulan Hasil Persilangan Ayam Bangkok, Legund dan Ayam Kampung. Skripsi. UNIPA, Manokwari (tidak diterbitkan).

Lebang, D. (2002). Perbandingan Performans Produksi Telur Ayam Kampung di Dataran Tinggi Anggi dan Dataran Rendah Manokwari. Skripsi. Fakultas Pertanian, Peternakan dan Kehutanan, UNCEN, Manokwari.

Lumatauw, S. A.L. Killian \& A. Supriyantono. (1995). Identifikasi Sifat-sifat Morfogenetik Ayam Buras di Irian Jaya. Laporan penelitian. Faperta Uncen, Manokwari.

Mu'in, M.A. (2000). Analisis Potensi Genetik Beberapa Ukuran Tubuh Ayam Kampung. Jurnal Irian Jaya Agro, 7(2): 38- 42. 
Prosiding Seminar Nasional Pembangunan dan Pendidikan Vokasi Pertanian

Politeknik Pembangunan Pertanian Manokwari, 31 Juli 2021

e ISSN : 2774-1982

DOI : https://doi.org/10.47687/snppvp.v2i1.190

Mulyadi, H., S.P. Atmodjo, \& Wihandoyo. (1981). Penggunaan Pejantan Broiler dalam Usaha Peningkatan Produksi Daging Ayam Silang Luar. Laporan Penelitian. Universitas Gadjah Mada, Yogyakarta.

Oziana, N., F. Agustinab, \& H. Moelyo. (2019). Sistem Pemeliharaan dan Kontribusi Usaha Ternak Ayam Lokal (Gallus Domesticus) terhadap Pendapatan Rumah Tangga Peternak. Journal of Integrated Agribusiness, 1(2): 107-114

Prasetyo, T., Subiharta, Wiloeto, D. \& M. Sabrani. (1985). Pengaruh Memisahkan Anak Ayam dari Induknya terhadap Kapasitas Produksi Telur. Seminar Peternak dan Forum Peternak Unggas dan Aneka Ternak. Balai Penelitian Ternak, Bogor.

Rahayu, B.W.I. (1990). Pengkajian Beberapa Sifat Phenotip Ayam Kampung di Kota Manokwari. Skripsi. Fakultas Pertanian, Universitas Cenderawasih, Manokwari.

Rajab. (2018). Pola pertumbuhan ayam kampung lokal periode starter pada pemeliharaan intensif. Jurnal Hutan Pulau-Pulau Kecil. DOI: 10.30598/jhppk.2018.2.1.123

Setiawan, A. (2007). Ayam Kampung Petelur. Penebar Swadaya, Jakarta.

Yuwanta, T., Nasroedin, Wihandoyo, Zuprizal \& A. Wibowo. (2002). The Role of Native Chicken in Indonesia Rural. The 3th ISTAP. Faculty of Animal Science, Gadjah Mada University.

Warwik, E.J., J.M. Astuti \& W. Harjosubroto. (1995). Pemuliaan ternak. Cetakan kelima. Gadjah Mada University Press, Yogjakarta.

Zurahmah, N. (2019). Performance of the local chickens on traditional management in Manokwari District, West Papua Province. The $8^{\text {th }}$ International Seminar on Tropical Animal Production, September 23-25, 2019, Yogyakarta, Indonesia. 